\title{
The Burning Temple
}

\author{
Religion and Conquest in Mesoamerica and the \\ Iberian Atlantic, circa I500
}

In I 535, an indigenous painter-scribe (tlacuilo) in the former Aztec capital of México-Tenochtitlán recorded the history of the Aztec Empire for the Spaniards who had defeated it (Fig. I.I). The first viceroy, Don Antonio de Mendoza, had recently arrived, and in order to rule over New Spain more efficiently, he had requested a record of the conquests and tributes of the former empire. In the pictographic language of indigenous codices that he had likely learned in temple schools (calmecac), the tlacuilo listed Aztec conquests by year, from the foundation of the empire around I428 until the arrival of the Spaniards in I5 I9. Page after page marks the subjugation of one altepetl (city-state, pl. altepeme) after another with the same glyph: a burning teocalli (temple), its thatch roof toppled, with grey volutes indicating smoke. Next to each burning teocalli is the placeglyph identifying the conquered polity: for example, in the bottom right corner of the image below, an eagle denotes Cuauhtitlán, or place of the eagles, an ancient city-state in the Valley of Mexico that had rebelled against the emperor. ${ }^{\mathrm{I}}$ The image lists the final conquests of Emperor Axayacatl, around I48I, a typical year of geostrategic challenges in which imperial armies were tied up in reconquering rebel city-states close to the capital while they sought to expand the northern frontiers ever further into the distant lands of the Huaxteca. ${ }^{2}$

${ }^{\mathrm{I}}$ Elizabeth Hill Boone, Stories in Red and Black: Pictorial Histories of the Aztecs and Mixtecs (Austin: University of Texas Press, 2000), 33-5.

2 Robert Hayward Barlow, "Conquistas de los antiguos mexicanos." Journal de la Société des Américanistes, vol. 36 (I947), 2 I 5-22. 


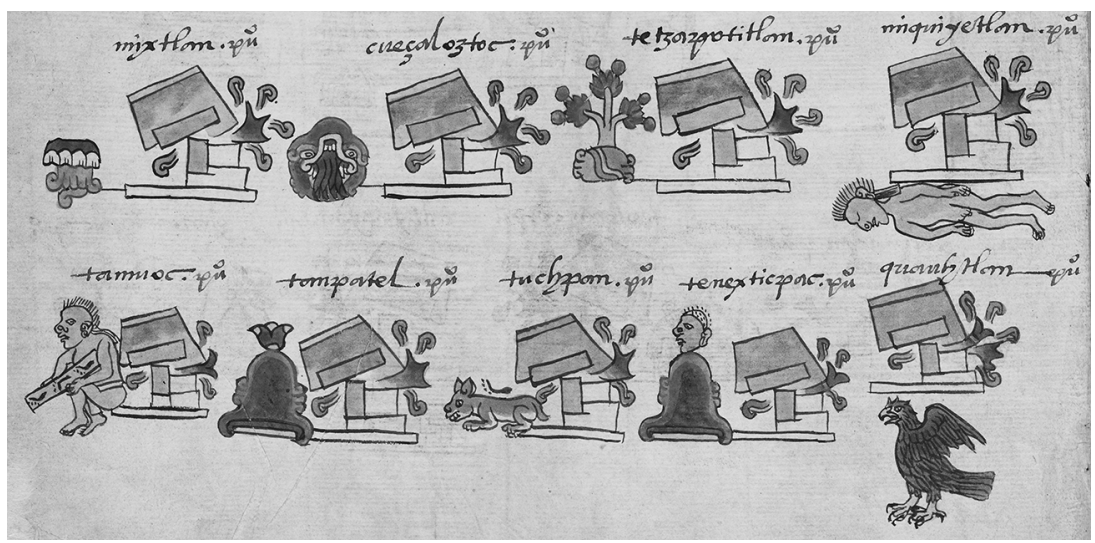

FIGURE I.I List of towns conquered by Emperor Axayácatl.

Anon. Indigenous tlacuilos, c. I 535, Codex Mendoza. Oxford Bodleian Library, Ms. Arch. Selden, A. I, f. Iov. Photo courtesy of Bodleian Libraries.

The burning temple represented an altepetl's loss of autonomy in the profoundest sense. The act "signified," David Carrasco writes, "that the structure, symbols, gods, energy and essences of a community have been destroyed." ${ }^{3}$ More than just a symbol, the temple was an edifice raised by the labor and contributions of all communities that formed part of the city-state. It was thus a tangible marker of a community's legitimate place among the city-states and confederations of Mesoamerica. Atop its frustum - the stone platform with steep steps popularly called "pyramids" - thatched chapels housed the patron gods, who embodied the distinct history of the city-state and sacralized the territorial claims of its local rulers. Conquering invaders would immediately set fire to this symbol of autonomy and seize the local patron gods, as if to appropriate the powers of those whom they had just vanquished. ${ }^{4}$

${ }^{3}$ David Carrasco, City of Sacrifice: The Aztec Empire and the Role of Violence in Civilization (Boston: Beacon Press, I999), 25; Fernando de Alva Ixtlilxóchitl, Obras históricas, ed. Edmundo O'Gorman, 2 vols. (Mexico City: UNAM, I977), vol. II, I03-4; Alonso de Zorita, Relación de los señores de la Nueva España, ed. Germán Vázquez (Madrid: Historia I6, I992), 95.

${ }^{4}$ Frances F. Berdan, Patricia Rieff Anawalt, eds., The Essential Codex Mendoza (University of California Press, 1997); Eloise Quiñones Keber, Codex Telleriano-Remensis: Ritual, Divination, and History in a Pictorial Aztec Manuscript (Austin: University of Texas Press, I995); Frances F. Berdan, The Aztecs of Central Mexico: An Imperial Society (Belmont, CA: Thomson Wadsworth, 2005), iा6; Richard F. Townsend, The Aztecs (London: Thames and Hudson, 2009), 80-3. 
Across Mesoamerica and the Iberian world in the fifteenth century, sacred structures - mosques, synagogues, animist godheads, and teocallis - went up in flames on frontiers of imperial expansion and marked a transfer of sovereignty. These acts and legacies of conquest, unconnected prior to the conquest of Mexico, converged there and shaped the development of the mission enterprise. That one should insist upon the importance of both Mesoamerican and Iberian legacies to understanding the mission in colonial Mexico is of obvious importance. But a third historical thread gets far less attention: the advancing, deadly wave of Spanish invasion, slave raiding, ecological crises, and demographic collapses that extended from the Canaries to the Caribbean, and then onward the American mainland. These early Atlantic encounters shaped Mexican missions as much as the politics of the Aztec Empire and latemedieval Iberia.

This chapter examines these three simultaneous histories of religion as a tool of conquest: the role of religion as an affirmation of Mesoamerican sovereignty, as an act of conquest in late-medieval Spain, and as a fragile legal sanctuary on the earliest Atlantic frontiers. Like a satellite hovering above the late-fifteenth and early-sixteenth century Atlantic world, it examines the ways in which these instances of religion and conquest came to influence the Mexican mission.

\section{CLAIMING A CORNER OF THE EARTH}

Templo Mayor (Great Temple), Tenochtitlán, I487. High above his proud imperial capital, Aztec Emperor Ahuitzotl ascended the steep steps of the Great Temple of Tenochtitlán and led a celebration that would go down in memory for the unsurpassed scale of its pageantry and bloodshed. A year had passed since his coronation, and Ahuitzotl had a debt of victories to pay with the blood of his war captives. When Ahuitzotl had returned from his frontier conquests, he distributed these prisoners to the wards of the city, where, for a time, they were treated like gods. But their enjoyment was short-lived. On the occasion of the rededication of the Great Temple, whose expansion he had overseen, Ahuitzotl decided to sacrifice them all. The emperor sent invitations to friends and foes alike to witness the ceremony. The spectacle astonished his guests: over four days, we are told, thousands of captives made their way in orderly lines through the city and up the staircase of the Great Temple, where Ahuitzotl and his high priests plunged obsidian knives into their chests, ripped out their hearts, and rolled their corpses down the sides of the pyramid. The blood 
of sacrificial victims pooled and flowed over the steps, encrusting between its stones. After the sacrifice was complete, Ahuitzotl lavished his guests with gifts and sent them home, no doubt with a new sense of dread of the Mexica. $^{5}$

The dedication of the Great Temple in 1487 exemplifies the overlap of religion and imperialism in Mesoamerica prior to the Spanish conquest. The Mesoamerican teocalli, or "god-house" in Náhuatl, represented an axis mundi that united the heavens with the earth. It was a recreation of Coatepec, the sacred mountain where their tribal god of war, Huitzilipochtli, was born. ${ }^{6}$ Huitzilipochtli was honored at the top of the structure, along with Tlaloc, the god of rain. Together they indicated the two vital forces of the Aztec world, warfare and agriculture. ${ }^{7}$ The Great Temple portrayed Aztecs as rulers in the "present moment," presiding over a world whose days were numbered, destined to be cut short by the cosmic cycle. But the present world could be prolonged, Aztecs claimed, through wars and sacrifices. ${ }^{8}$ This immense sacred structure grew in tandem with the empire, feeding upon the ever-rising numbers of captives and tributes that flowed from the frontiers towards the institutions at the core of Tenochtitlán. The Great Temple was thus an expression of both worldly and spiritual power: it anchored an empire that saw itself, in the words of the Texcocan King Nezahualpilli the Elder, as "the root, navel, and heart of this entire apparatus of the world." It embodied Aztec efforts to rule over a corner of the earth and over an epoch that dangled on the precipice of cataclysm. ${ }^{\text {IO }}$

As the Great Temple grew with each generation, the structure showcased how far the Mexica had come. Their beginnings were humble. They arrived in central Mexico sometime in the twelfth century as outsiders, one of several tribes that had abandoned the deserts of the north for the sedentary comforts of the altiplano city-states. ${ }^{\text {II }}$ These nomads moved

5 Diego Durán, History of the Indians of New Spain, trans. and ed. Doris Hayden (Norman: University of Oklahoma Press, 1994), 328-43; Nigel Davies, The Aztecs (Norman, OK: University of Oklahoma Press, I980), I65-7.

${ }^{6}$ Carrasco, City of Sacrifice, 59-60; Eduardo Matos Moctezuma, Tenochtitlán (Mexico City: Fondo de Cultura Económica, 2010), 87-9.

7 Matos Moctezuma, ibid., 90.

${ }^{8}$ Richard F. Townsend, State and Cosmos in the Art of Tenochtitlán (Washington, DC: Dumbarton Oaks Research Library and Collection, I979), 56; Townsend, The Aztecs, I3 $8-43$.

9 Matos Moctezuma, Tenochtitlán, 8I. $\quad{ }^{\text {Io }}$ Carrasco, City of Sacrifice.

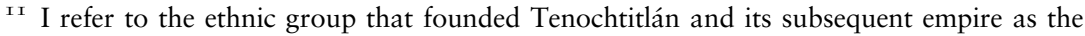
Mexica, but I use the term "Aztec" to denote the empire, its officials, and its bureaucracy 
with their patron gods safely stored in sacred bundles under the leadership of rulers, many of whom would later be deified. ${ }^{\mathrm{I} 2}$ The Mexica took full advantage of the collapse of the Toltec Empire as central Mexico fragmented into dozens of warring city-states, entering the breech and stepping into Mesoamerican history. They first hired themselves out as mercenaries, but over time the hereditary leaders of kinship groups within the tribe intermarried with Toltec elites. This produced a noble class with a mixed nomadic and imperial heritage, and as the Mexica gained influence they developed this legacy into a claim to rule. ${ }^{13}$ In 1325 , they established their altepetl at Tenochtitlán, a low-lying island in Lake Texcoco, by erecting a temple to their patron god. According to Mexica myth, they settled there after seeing the divine sign that their priests had foretold centuries earlier: they found an eagle perched on a cactus, devouring a serpent. Over the following decades they fought innumerable wars as mercenaries and allies, and their rulers married into regional dynasties. Then, in I428, they conquered Azcapotzalco, their former masters. This marked the foundation of the Aztec Empire. ${ }^{4}$ The Mexica thus passed from the "hunger, poverty, and suffering" of migration to the indignity of "[having] to pay tribute to other provinces," to ruling over a "free and prosperous city...the queen of all cities, all of which pay tribute to her." ${ }^{\text {I5 }}$

Itzcoatl, the founding Aztec Emperor, consolidated his authority by setting fire to codices that recorded inconvenient precedents of Mexica commoners having a say in the affairs of the polity. ${ }^{16}$ He replaced these

since the empire incorporated a vast array of ethnic groups. "Aztec" derives from "Aztlán," the mythical homeland of the tribe. "Mexica" derives from "Mezitin" or "Meçitl," a priest who initiated the migration. Durán, History, 3-30; Rudolph van Zantwijk, The Aztec Arrangement: The Social History of Pre-Spanish Mexico (Norman, TX: University of Oklahoma Press, 1985), 38-43; Sahagún, Florentine Codex, vol. XI, I 89-9I.

${ }^{12}$ Guilhem Olivier, "Les paquets sacrés ou la mémoire cachée des indiens du Mexique central (XV-XVI siècles)." Journal de la Société des Américanistes, vol. 8I (I995), I05-4I; Alfredo López Austin, Hombre-dios: Religión y política en el mundo náhuatl (Mexico City: UNAM, I998), I06-60; Geoffrey Conrad and Arthur A. Demarest, Religion and Empire: The Dynamics of Aztec and Inca Expansionism (Cambridge: Cambridge University Press, I998), 26-8.

${ }_{13}$ Townsend, State and Cosmos, IO-I; Conrad and Demarest, Religion and Empire, 24-7.

${ }^{14}$ Davies, Aztecs, 35-9; Van Zantwijk, Aztec Arrangement, 57-82; Conrad and Demarest, Religion and Empire, 59-6I.

I5 This tale of the Mexicas' transformation appears in a chapter of Diego Durán's chronicle that narrates an expedition to the northern deserts sent by Moctezuma to find Aztlán in the fifteenth century. Durán, History, 2 I 8. See also Townsend, State and Cosmos, I 2, 22.

${ }^{16}$ Sahagún, Florentine Codex, bk. I0, ch. 29. 
local histories with an imperial narrative that paralleled his tribe's ascent to power with the tale of their tribal god's ascent to solar deification. Around Huitzilipochtli, and the Great Temple dedicated to him, the Aztec regime built a state religion that served expansion by conquest. ${ }^{17}$ The central tenet of this imperial cult "held that the Mexica must relentlessly take captives in warfare and sacrifice them ... [in order to] strengthen the sun and stave off its inevitable destruction by the forces of darkness." ${ }^{8} 8$ By anointing themselves the foremost "mortal collaborators" with the gods, the Mexica turned practices long extant in Mesoamerican agricultural rites into a tool of subjugation. ${ }^{\text {I9 }}$

Aztec imperialism might have been as sharp-edged as the obsidian blades that cut into its war captives, but in administrative terms it was complex web of overlapping sovereignties. In many respects the Aztec Empire was an extended family, for the ruling dynasties of the city-states that were incorporated into it, whether by force or through alliances, intermarried with the Mexica elite. ${ }^{20}$ The empire was a vast elite network that made the gap between nobles and commoners ever starker. ${ }^{2 \mathrm{I}}$ Local ruling elites had wide berth to rule over their jurisdictions according to their customs on condition that they served in imperial wars, paid tributes regularly, delivered war captives, and heeded royal invitations. ${ }^{22}$ Set to consume these offerings of subject populations, the empire became overextended. Its rulers had to unceasingly pursue conquest without paying sufficient attention to consolidating their power in order to maintain this imperial economy of tributes and sacrifices. ${ }^{23}$

If we look beyond the imperial elite and their capital, the Aztec Empire presented a fragmented political landscape of several hundred semiautonomous altepetls. Like the Mexica altepetl of Tenochtitlán, each

${ }^{17}$ Conrad and Demarest, Religion and Empire, 32-4, 38; Townsend, State and Cosmos, 54.

18 Conrad and Demarest, ibid., 38.

19 Townsend, State and Cosmos, 53-4; Conrad and Demarest, Religion and Empire, 48.

${ }^{20}$ Frances F. Berdan and Michael E. Smith, "Imperial Strategies and Core-Periphery Relations," in Aztec Imperial Strategies, eds. Frances F. Berdan, Richard E. Blanton, et al. (Washington, DC: Dumbarton Oaks, I996), 2 I I.

${ }^{21}$ Michael E. Smith, "The Role of Social Stratification in the Aztec Empire: A View from the Provinces." American Anthropologist, vol. 88 (I986), 70-9I; Michael E. Smith, Aztec City-State Capitals (Gainesville: University of Florida Press, 2008), I I-2; Ross Hassig, Aztec Warfare: Imperial Expansion and Political Control (Norman, OK: University of Oklahoma Press, I988), 20I-3.

${ }^{22}$ Davies, Aztecs, Iro-2; Michael E. Smith, The Aztecs (Malden, MA: Wiley-Blackwell, 20I2), I 53-65.

${ }^{23}$ Conrad and Demarest, Religion and Empire, 53. 
altepetl also boasted its own hereditary rulers (tlatoque, sing. tlatoani), a class of nobles (pipiltin, sing. pilli), palace (tecpan), market (tianquiztli), and temple (teocalli). ${ }^{24}$ Each altepetl told its own story of exceptionalism, but for all their diversity they drew upon a common source of Mesoamerican origin histories and foundational narratives. ${ }^{25}$ Each altepetl also boasted its own patron gods, carefully borne in sacred bundles during their migrations from the deserts: Mexica carried turquoise (chalchibuite) and kindling in memory of their patron god's gift of fire, while the Texcocans bore Tezcatlipoca's obsidian mirror, which aided in foretelling the future. ${ }^{26}$ In the Mixtec city-state $(\tilde{n} u u)$ of Tlaxiaco in Oaxaca, a collection of figures of green gemstone were held in such reverence that a Dominican friar in the sixteenth century referred to them as the corazón del pueblo - "the heart of the town," or put another way, "the heart of the people." ${ }^{27}$

The history of many central Mexican altepeme spoke of migration, intermarriage with local inhabitants, and the founding of their permanent settlement, a seminal event that marked their exodus from nomadism to sedentary life. They built temples for their patron gods, marking a new permanent home for the tribe and its divine protectors. ${ }^{28}$ But each altepetl was also a sacred kingdom. In Náhuatl, altepetl means "water-mountain," a term more far-reaching than urbs (the fabric of the city) or even civitas (the society dwelling within it). The altepetl was a rinconada, a corner of the earth where the mountain - which was sacred because it drew rain from the heavens - met the alluvial plain, the place of

${ }^{24}$ Smith, Aztecs, I 53-4; Lockhart, Nahuas, I4-5; Susan Schroeder, Chimalpahin and the Kingdom of Chalco (Tucson: University of Arizona Press, I99I), II9-53.

${ }^{25}$ López Austin, Hombre-dios, 52.

${ }^{26}$ López Austin, ibid., 58-9; Townsend, State and Cosmos, 34.

27 Burgoa, Geográfica descripción, vol. I, 332-3.

${ }^{28}$ Schroeder, Chimalpahin, I2 I; Smith, Aztec City-State Capitals, 74-83; Pablo Escalante Gonzalbo, "El patrocinio del arte indocristiano en el siglo XVI. La iniciativa de las autoridades indígenas en Tlaxcala y Cuauhtinchan," in Patrocinio, colección, y circulación de las artes, ed. Gustavo Curiel (Mexico City: UNAM, I997), 2 I 8-9; David Carrasco and Scott Sessions, ed. Cave, City, and Eagle's Nest: An Interpretive Journey through the Mapa de Cuaubtinchan no. 2 (Albuquerque: University of New Mexico Press, 2007). On sacred bundles, see: Olivier, "Les paquets"; Werner Stenzel, "The sacred bundles in Mesoamerican religion," Thirty-eighth International Congress of Americanists, vol. 2 (1968), 347-52. Despite significant cultural variations, in general terms this political structure also characterized local native polities in other sedentary societies in Central Mexico such as the Mixtecan ñuu of Oaxaca and the Purhépecha ireta in the Kingdom of Michoacán. On the Mixteca, see Terraciano, Mixtecs, 347-8; for Michoacán under the Tarascan Empire, see Rodrigo Martínez Baracs, Convivencia y utopía: El gobierno indio de la "ciudad de Mechuacan" (Mexico City: Fondo de Cultura Económica, 2005), 56. 
abundance, agriculture, and settlement. At the core of the altepetl, the teocalli marked sovereign claims over surrounding lands. ${ }^{29}$ Its solidity represented a struggle against impermanence, for the inhabitants were attached to their land not solely because their roots extended back to time immemorial, but also because their collective memory recalled the pains of migration, hunger, and poverty. They were determined not to return to those periods of want and wandering. The temple, and later the community church, was an expression of this will.

In its internal composition, each altepetl consisted of wards called calpoltin (sing. calpolli). In general, calpoltin were made of "groups of families that lived near one another, were subject to a local lord, controlled a block of land, and often shared a common occupation." ${ }^{30}$ In some areas they were formed by ethnic minorities within an altepetl. ${ }^{3 \mathrm{I}}$ This was the most basic social unit in central Mexican society, arguably the most vital site in the economic and political lives of commoners (macehualtin, sing. macehual). Membership in the calpolli gave them the right to cultivate a plot of land in usufruct in exchange for tributes and draft labor. ${ }^{32}$ Each calpolli was thus like a miniature altepetl, boasting its own hereditary nobility, palace, and teocalli dedicated to its patron-god (calpulteotl). ${ }^{33}$ In principle, all calpoltin had equal weight within their altepetl, but in practice the wealthier calpulli tended to dominate the others. ${ }^{34}$ Prior to Aztec expansionism, commoners had carried greater influence in their calpoltin, electing their rulers and extracting concessions for their labor and tribute. Class differences

29 María Elena Bernal García and Ángel Julián García Zambrano, "El altepetl colonial y sus antecedents prehispánicos: contexto teórico-historiográfico," in Territorialidad y paisaje en el altepetl del siglo XVI, eds. Federico Fernández Christlieb and Ángel Julián García Zambrano (Mexico City: Fondo de Cultura Económica, 2006), 46-8, 99-ıoI; Van Zantwijk, Aztec Arrangement, 200-I.

30 Smith, The Aztecs, I35; Matos Moctezuma, Tenochtitlán, 77.

${ }^{31}$ Lockhart, Nahuas; Dana Leibsohn, Script and Glyph: Pre-Hispanic History, Colonial Bookmaking, and the Historia Tolteca-Chichimeca (Washington, DC: Dumbarton Oaks Research Library and Collection, 2009), I9-23.

32 Smith, The Aztecs, I35-6; Rebecca Horn, Postconquest Coyoacan: Nahua-Spanish Relations in Central Mexico, I519-1650 (Stanford: Stanford University Press, I997), 20-2.

33 Matos Moctezuma, Tenochtitlán, 77; Smith, Aztec City-State Capitals, 90; Conrad and Demarest, Religion and Empire, 23; López Austin, Hombre-dios, 47-52.

${ }^{34}$ Lockhart, Nahuas; Conrad and Demarest, Religion and Empire, 24; Pedro Carrasco, "Social Organization of Ancient Mexico," in eds. R. Wauchope et al., Handbook of Middle American Indians, vol. ıо, 366. 
rigidified, however, as Aztec imperialism widened the gap between nobles and commoners. ${ }^{35}$ Ultimately, the authority of an altepetl - and by extension, of the empire - consisted in the ability of local and imperial elites to mobilize calpoltin in the tasks of farming, taxpaying, and soldiering. ${ }^{36}$

Like a matryoshka doll, each unit in Mesoamerican politics shared the same fundamental characteristics. Each calpolli and altepetl was anchored by a teocalli, which represented the history of the local group. Long after Spaniards physically demolished the teocalli, they would still have to reckon with its afterlife - with the ways in which these sacred structures defined relations, identities, and territorial claims in hundreds of calpoltin and altepeme. Within each unit, tribute payments and participation in religious rites confirmed political authority. Local rulers, in turn, distributed tributes to reward their subjects and pay respect to their overlords. And in order to bring the rains down from the sacred mountain to irrigate their crops, priests made offerings of copal, sage, and blood. Native students of fray Bernardino de Sahagún eloquently explained this religious system of serving gods and life-forces:

It was the doctrine of the elders that there is life because of the gods; with their sacrifice, they gave us life.

It was their doctrine that the gods provide our subsistence, all that we eat and drink, that which maintains life: maize, beans, amaranth, sage.

To them do we pray

for water, for rain

which nourish things on earth. ${ }^{37}$

The scale of the sacrifice to keep the world in balance only grew from one level to the next, from humble calpoltin to proud altepeme to the allconsuming imperial capital.

35 Conrad and Demarest, Religion and Empire, 36-8; Elizabeth M. Brumfiel, "Aztec State Making: Ecology, Structure, and the Origin of the State." American Anthropologist, vol. 85 (I983), 269-7I.

${ }^{36}$ Smith, Aztec City-State Capitals, 9I; Escalante Gonzalbo, "El patrocinio," 217; Berdan and Smith, "Imperial Strategies," 21 5-I7.

37 Miguel León Portilla, Aztec Thought and Culture, trans. ed. J. E. Davis (Norman, OK: University of Oklahoma Press, 1963), I 58-66. 
Aztec imperialism derived its power from the life forces of its subject populations. Tribute payments in commodities fed the residents of the growing capital, while payments in luxury goods - feathers, gold lip plugs, bracelets, jade stones, and ocelot skin garments - adorned temples, priests, and warriors. These precious goods also provided Mexica rulers with a currency of power, since they redistributed these goods as rewards and diplomatic gifts. ${ }^{38}$ Altepeme also demonstrated their subjugation to the empire by channeling the labor of their commoners to construction projects like the vast hydraulic programs that desalinated Lake Texcoco and reclaimed new lands for cultivation..$^{39}$ Most significant, however, was the labor that subject altepeme provided for construction in the imperial capital. Building temples served "as a measure of political fealty" as much as it was a display of "piety." ${ }^{\circ}$ When Emperor Moctezuma I erected his temple to Huitzilipochtli, he called upon surrounding altepeme to provide materials and labor: Texcoco built the front, Tacuba the back, Otomí communities provided sand, and lowland communities brought lime. ${ }^{4 \mathrm{I}}$ To refuse such demands effectively amounted to a declaration of independence that invited certain war, as befell Chalco after it rejected one such invitation from Moctezuma. ${ }^{42}$

Aztec conquests not only consumed the things of this world; they also absorbed the sacred forces of conquered and subject peoples. The toppling of temples in the heat of war may have marked conquest, but this violence was not necessarily iconoclastic. On the contrary: Aztec conquerors tended to appropriate foreign gods and thereby absorb their forces. They seized sacred relics and brought them to Tenochtitlán, where the Mexica placed them in the coateocalli, a pantheon where "all the gods could be adored." ${ }^{43}$ On some occasions Aztec conquerors even captured local priesthoods in conquered areas and took them to Tenochtitlán to serve in the coateocalli. After the Aztecs conquered the Toluca Valley in

${ }^{38}$ Berdan, Aztecs of Central Mexico, 4I-7.

39 Brumfiel, "Aztec State-Making," 275; Berdan, Aztecs of Central Mexico, 42; Hodge, "Political Organization of the Central Provinces," in ed. Berdan, Blanton et al., Aztec Imperial Strategies," 26.

${ }^{40}$ Hassig, Aztec Warfare, I 59; Berdan, Aztecs of Central Mexico, I I3. $\quad{ }^{41}$ Hodge, ibid.

${ }^{42}$ Hassig, ibid.; See also Durán, History, I05.

${ }^{43}$ Hassig, Aztec Warfare, I05. In many cases local populations hid their sacred bundles to avoid seizure of their gods, as occurred after the Spanish conquest. See Patricia Lopes Don, Bonfires of Culture: Franciscans, Indigenous Leaders, and Inquisition in Early Mexico, I524-I540 (Norman: University of Oklahoma Press, 20IO), I I I-45. Durán, History, $43 \mathrm{I}$. 
the I490s, the conquerors erected a temple in Tenochtitlán dedicated to the god of the defeated Matlatzincas, where he "received sacrifices." 44 Thus, while Spanish conquerors and missionaries had the goal of annihilating all deities and forms of worship other than their own, the Mexica and Mesoamericans in general - were accustomed to incorporate foreign gods into their religion. ${ }^{45}$ Fray Toribio de Benevente Motolinía, one of the first Franciscan missionaries in Mexico, despaired of this difference when he found images of the Virgin Mary placed next to idols during his first years in Mexico: "Since they had a hundred gods before, now they wanted a hundred-and-one." ${ }^{46}$

The tale of the birth of the Mexicas' patron god Huitzilipochtli encapsulates Aztec politics. Atop the sacred mountain of Coatepec, the earth goddess Coatlicue found herself under attack by her children at the moment she was going into labor. Vowing revenge inside the womb, Huitzilipochtli cut himself out of his mother and immediately donned battle dress. He swept down on his sister Coyolxauhqui, who had incited his siblings to rebel, chopped her to pieces, and tossed her down from the sacred mountain. He then stripped his other siblings of their ornaments, seized their holy relics, and massacred them all. Huitzilipochtli thus "transformed their obliteration into his own power." ${ }^{47}$ In similar fashion, precious objects from the far corners of the Aztec empire were arrayed throughout the Great Temple so that the Mexica who served the gods could increase their sacred and temporal powers. ${ }^{48}$ So sang Huitzilipochtli:

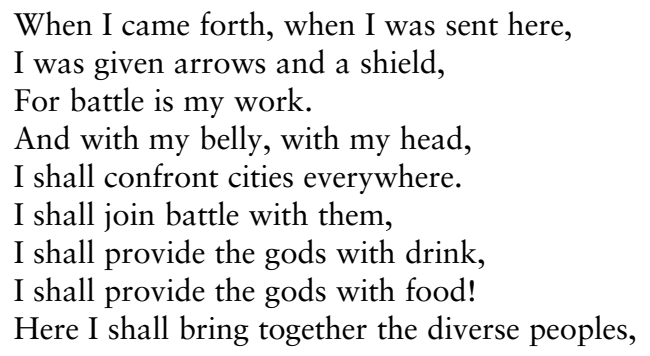

${ }^{44}$ Emily Umberger, "Art and Imperial Strategy in Tenochtitlán,” in ed. Berdan et al., Aztec Imperial Strategies, 93; Conrad and Demarast, Religion and Empire, 44-8; Townsend, State and Cosmos, 42-3; Van Zantwijk, Aztec Arrangement, I I 2; Smith, Aztec City-State Capitals, 203.

45 Townsend, State and Cosmos, 36.

${ }^{46}$ Toribio de Benevente Motolinía, Historia de los indios de la Nueva España, ed. Edmundo O’Gorman (Mexico City: Porrúa, 200I), 29.

47 Carrasco, City of Sacrifice, 63. $\quad{ }^{8}$ Carrasco, ibid., 58-63. 
And not in vain, for I shall conquer them, That I may see the house of jade, the house of gold, The house of quetzal feathers... ${ }^{49}$

\section{ALL THE MOSQUES ARE NOW CHURCHES}

Parish Church of Santa Fé de Granada, December 20, I499. In the late afternoon, around the hour of the winter sunset, a Muslim woman named Fatima slowly inched forward in line toward the altar of the church. There, one by one, Granadan Muslims renounced their religion and were inducted into the Christian faith by the most powerful churchman in Spain, Cardinal Fray Francisco Jiménez de Cisneros, the Archbishop of Toledo. It was an improvised affair. Old Christian godparents took turns to sponsor the masses of converts, and scribes hastily recorded the head of each household's Muslim and new Christian names, their dependents, domicile, and trade. Like many of the other women in line that day, Fatima was listed in the baptismal record as the head of a household, perhaps because she had been widowed during Granada's war against the Spaniards that had concluded with the final defeat of this last Muslim kingdom on Iberian soil in I492. She joined a diverse array of Granadan society. Granadan royalty, African slaves, tradesmen, and farmers all waited to receive a baptism that, by all appearances, none desired..$^{50}$

For seven years, Castilian conquerors and local Muslim alguaciles (alwazir, community leaders) had been promising that defeat would not lead to the heartbreaking scene that Fatima now beheld: a panicked rush to the baptismal font. ${ }^{5 \mathrm{I}}$ Over the previous weeks the pressures to convert had been mounting. Cardinal Cisneros had arrived in the city with a cadre of militant Franciscans under the pretext of investigating elches, Christian renegades who had been living as Muslims for decades. ${ }^{52}$ The Franciscans

49 Timothy J. Knab, ed. A Scattering of Jades: Stories, Poems, and Prayers of the Aztecs, trans. Thelma D. Sullivan (Tucson, AZ: University of Arizona Press, I994), 87.

$5^{\circ}$ Cisneros papers, AHN Universidades, leg. 720 , ff. $48 \mathrm{r}-240 \mathrm{ov}$ and $297 \mathrm{r}-34 \mathrm{ov}$. Over eight thousand names are listed over a three-month period from November I499 to February I 500 . This description of the baptism of Dec. 20 I 499 is drawn from ff. 68r-72v. Ladero Quesada points out the large number of women listed as heads of households - scars of the devastating war that only concluded nine years before. See "Nóminas de conversos granadinos (I499-I 500)," in Estudios sobre Málaga y el Reino de Granada en el $V$ centenario de la Conquista (Málaga, 1987), 296-303.

${ }^{5}$ Miguel Ángel Ladero Quesada, Granada después de la conquista: repobladores y mudéjares (Granada: Diputación Provincial de Granada, I988).

${ }^{52}$ Investigation into elches (I499), AHN Universidades, leg. 720, f. $282 \mathrm{r}$. 
quickly went beyond their original task and started to preach in Muslim quarters. Ecclesiastical authorities arrested local Muslim leaders who protested, which provoked rioting throughout the city. ${ }^{53}$ Spanish Christians declared the street violence a rebellion, and soon Granadan Muslims found themselves facing the choice of conversion or expulsion. Whatever duress Fatima confronted that tense December was enough to send her to the baptismal font on the fourth day of mass conversions that would continue for another three months. She joined a hundred and forty others in line. When the Cardinal or one of his attendants sprinkled holy water over her at the altar, Fatima became Catalina. Afterwards she stepped back out into a city that, like her, was being converted through force and fear to Christianity. ${ }^{54}$

If Ahuitzotl's line of war captives fed and enlarged his empire, Cisneros' line of sorrowful converts was a step towards reducing the world to "one faith and one baptism." "55 The mass conversion of Granadan Muslims of I 499-I 500, and the subsequent expulsion of those who refused to convert, was a watershed in Castilian Christian efforts to end the multi-religious coexistence, known as convivencia, that had shaped medieval Iberia for hundreds of years. This was a plural, interdependent, but also antagonistic coexistence of Muslims, Jews, and Christians. ${ }^{56}$ Contrary to the optimistic views of some, convivencia was born more of necessity than of cosmopolitanism. Both Muslim and Christian conquerors were willing to set aside their desires to convert the rival faiths in exchange for payments of tribute from them. In 1086 the Almoravid conqueror Yusuf Ibn Tasufin made such an offer when he gave defeated Christians and Jews the option of either converting to Islam or paying the jizya, a tax guaranteeing protection to monotheists, or "people of the book." ${ }^{57}$ When Christian kings conquered

${ }^{53}$ Luís del Mármol Carvajal, Rebelión y castigo de los moriscos (Málaga: Editorial Arguval, I99I), 6I; Ladero Quesada, "Nóminas," 228, 255; Juan Vallejo, memorial, AHN Universidades, leg. 7I6, f. 9 r.

54 AHN Universidades, leg. 720, f. 7Iv.

55 Jesús Suberbiola Martínez, El Real Patronato de Granada: El Arzobispo Talavera, la Iglesia, y el estado moderno (Granada: Caja General de Ahorros y Monte de Piedad de Granada, I985), I89.

${ }^{5}$ David Nirenberg, Communities of Violence: Persecution of Minorities in the Middle Ages (Princeton: Princeton University Press, I996); Charles J. Halperin, "The Ideology of Silence: Prejudice and Pragmatism on the Medieval Religious Frontier." Comparative Studies in Society and History, vol. 26, no. 3 (July I984), 443-9. For a foundational - if rose tinted - examination of convivencia, see Américo Castro, La realidad histórica de España (Mexico City: Porrúa, 1987).

57 Emilio García Gómez, "Novedades sobre la batalla llamada de Al-Zallaqa (I086), una versión oficial de la batalla." Al Andalus, vol. I 5 (I950), I27-33. 
Muslim territories, they followed Muslim precedents by levying similar taxes on Muslims and Jews. ${ }^{8}$ Doing so was the path of least resistance, but it flew in the face of Christian hope for the triumph of the faith over infidels.

Convivencia unraveled over the course of the fifteenth century amid rising social tensions. In Castilian cities, Christian populations launched pogroms against religious minorities. On the streets, in synagogues, and in mosques, convivencia was preached, legislated, beaten, and burned out of existence. In I 476 and I 480 , representatives at the Castilian parliament abolished the last remaining legal protections for Jews and Muslims that dated to the thirteenth century. ${ }^{59}$ Shortly thereafter civil and ecclesiastical authorities created the Inquisition to police Christian orthodoxy and guard its boundaries against the influences of Islam and Judaism. The end of convivencia reflected a desire, among nobles and commoners alike, to see Christianity triumph at the cost of its competitors. It was a notion of religious exclusivism that would soon make its way across two oceans.

Although the Catholic Kings conquered Granada in the same year that they expelled all Jews who refused to convert to Christianity, their initial policies towards native Muslims in the former Nasrid kingdom reprised convivencia. Set high in the sierras of Eastern Andalucía, the kingdom was a vast Muslim land that was at once foreign and familiar. For the moment prudence outweighed evangelism. In the pacts of surrender signed in $\mathrm{I} 492$, the Crown guaranteed Muslim rights to their own religion and law on condition that they paid a head-tax. The capitulations abolished the native Nasrid monarchy, but they maintained local power structures in the aljamas, parish-sized districts that oversaw the administration of justice and tax-collection. ${ }^{60}$ During the I490s this social order preserved the delicate peace between Christian colonists and Muslim

${ }^{8}$ The Siete Partidas, the thirteenth-century Castilian legal code, replicated Islamic laws concerning dhimmis (Jews and Christians, or "people of the Book"). According to the Pact of 'Umar, the integrity of dhimmi communities, including the rights to worship and autonomous regulation, were guaranteed on condition that the community paid a community tax (jizya). See Norman A. Stillman, The Jews of Arab Lands: A History and Source Book (Philadelphia: Jewish Publication Society of America, I979), I 58 ; Gregorio López, Siete Partidas (Madrid: Boletín Oficial del Estado, I974 [I 555 ]), 6:7:2.

59 Manuel Colmeiro, ed. Cortes de los antiguos reinos de León y de Castilla (Madrid, I 883), vol. II, 49, 63 .

60 Ángel Galán Sánchez, "Poder cristiano y 'colaboracionismo' mudéjar en el Reino de Granada (I485-I 50I)," in Estudios sobre Málaga y el Reino de Granada en el V Centenario de la Conquista, ed. José Enrique López de Coca Castañer (Málaga: Diputación Provincial, I987), 272, 285. 
natives. As Queen Isabel assured aljama leaders, “our will is that no Moor will be forced to become Christian." ${ }^{61}$ Shortly thereafter Cisneros arrived in Granada with his campaign of provocation.

After the mass baptisms of thousands like Fatima came the symbolic reordering of city life: Cisneros marked the end of the public presence of Islam in Granada with a bonfire of all the Korans that could be found. ${ }^{62}$ As Muslim leaders had either converted or fled, clergymen consecrated the mosques. "All of the mosques are now churches," Cisneros proudly reported to his colleagues in Toledo, "and the same infidels who were our enemies are now witnesses." ${ }_{3}$ Cisneros urged royal officials to make conversion to Christianity the primary condition of vassalage to the Crown; accordingly, in I 502, Fernando and Isabel declared that Christianity would be the sole legal religion in Castile. For Cisneros, the order in which peace was to be made was clear. When Castilian captains and missionaries entered negotiations with Muslim rebels in the Alpujarra Mountains, he stated: "Pray to the Lord that first their souls make peace with God, because without this there will be little advantage in ruling over their bodies." ${ }^{64}$

Making conversion a condition of surrender laid a precedent for subsequent Spanish conquests. Cisneros and his Franciscans knew of the injunctions of canon law that required clerics to instruct nonbelievers prior to conversion, but they justified mass baptism by invoking an emergency procedure, known as "urgent need," which allowed them to redeem infidels without prior indoctrination in times of war or duress. Instruction would come later, under the aegis of a colonial regime whose entire raison d'être would be to support evangelization with arms and treasure. Over the following decades missionaries converted multitudes under the presumption that conquest aided their project of conversion. ${ }^{65}$ This informed those who set policy for new Spanish conquests in the Caribbean. Eleven years after the completion of the Granada campaign, one of Cisneros' collaborators in the councils of state, Juan López de Palacios Rubios, institutionalized the practices that had been emerging on

6I Ladero Quesada, Los Mudejares, I 28.

62 AGS Cédulas de la Cámara, libro 27, f. 22 r.

${ }^{63}$ Cisneros to Cathedral Chapter of Toledo (I 500), in Ladero Quesada, Los mudéjares, 236.

${ }^{64}$ Cisneros to Dean of the Cathedral of Toledo (I 500 ), BNE, ms. I3020, f. 94.

${ }^{65}$ Parecer sobre si los infieles pueden ser atraídos a la fee, pusiendolos en necesidad, AHN Universidades, leg. 720 , f. $7 \mathrm{r}-\mathrm{v}$; for papal approval of this method as practiced in Granada, AGS Patronato Real, leg. 65, exp. 95. 
Spanish frontiers. ${ }^{66}$ The most notable of these was the requerimiento, or "requirement," that made the acceptance of missionaries a fundamental condition of subjection to the Spanish Crown.

Palacios Rubios intended for conquistadors to read the requerimiento to natives before they initiated hostilities against them. The text explained the reasons why Spaniards were entitled to make "just war": unbeknownst to them, the Pope had "donated" native lands to the Catholic Kings in I494, ostensibly as an act of grace. Natives faced two choices which they would be allowed to deliberate for an "appropriate amount of time." If they desired peace, they would have to acknowledge the Church as "lord of the universal world," submit to the king of Spain as their temporal lord, and allow priests into their communities. But if they did not accept, the text warned, "and if they "maliciously" delayed their response,

I swear to you that with the help of God we will enter with force against you and make war upon you everywhere ... and we will subject you to the yoke and obedience to the Church and his Majesty, and we will take you, your wives and your children, and we will sell them as slaves and dispose of them as their Majesties command, and we will take your goods and do all of the terrible things and damages that we can do to vassals who do not obey nor want to receive their lord.

The message ended with an extraordinary disclaimer: "And we vow that the deaths and damages resulting from that shall be your fault and not of their Highnesses nor of these gentlemen that came here with us." ${ }^{\circ 7}$ Conquistadors infamously read the protocol without interpreters before sacking native villages, solely to make sure that the record of their warfare was unassailable. With good reason the text has been dismissed as a legal absurdity for half a millennium. Fray Bartolomé de las Casas famously remarked that he was not sure whether to laugh or cry when he first heard of it. ${ }^{68}$

Absurd though it was, however, the requerimiento provides a snapshot of how the end of convivencia in Iberia shaped Spanish conditions of peace and war in the New World. The primary Spanish condition of peace in the

${ }^{66}$ Manuel Giménez Fernández, Bartolomé de las Casas: Delegado de Cisneros para la reformación de las Indias (Seville: Escuela Superior de Estudios Hispano-Americanos, I953), 66, I4I.

67 Bartolomé de las Casas, see Historia de las Indias, ed. Agustín Millares Carlo (Mexico City: Fondo de Cultura Económica, I95I), vol. III, 27. Three other versions can be found in Francisco Morales Padrón, Teoría y leyes de la conquista (Madrid: Ediciones Cultura Hispánica del Centro Iberoamericano de Cooperación, I979), 338-45.

${ }^{68}$ Las Casas, Historia, vol. III, 3 I. 
requerimiento is the native reception of preachers, followed by the natives' conversion to Christianity. While the emissary does state that "they [Spanish soldiers and missionaries] will not force you to become Christians" - a nod to theologians who insisted that true faith was only voluntary - the text clearly states that conversion to Christianity is the only insurance of personal freedom and private property ${ }^{69}$ Peace depended upon the indigenous community's willingness to receive preachers. But in the longer term, delay was also grounds for just war. In his treatise De las islas del mar océano a few years prior to the requerimiento, Palacios Rubios wrote: "The natives are obliged to admit preachers of our holy faith so that they can explain in detail all of its mysteries to them. And if, after a prudent period to decide, they decide not to do it, they can be invaded." 70 These terms clearly contrasted with the agreements of convivencia, which allotted a space for conquered religions at the price of paying tribute $(j i z y a) .^{7^{I}}$ Granadan Muslims, Canary Islanders, Caribbean natives, and the Mexica of Tenochtitlán met with far starker terms than most conquered peoples in medieval Iberia. After I 500, the condition of peace was to extinguish native faiths, publicly accept Christianity, and pay tribute to new rulers.

The aggressive policies that brought about the conversion of natives like the Granadan widow Fatima allowed Spaniards to entertain achieving a long-unattainable ideal of Christian universalism. Christians had prayed for the conversion of the infidels in their midst and at the edges of the world during convivencia, but political conditions and habits militated against serious evangelization. Theologians, especially Hostiensis, had long argued that Christendom, with the Pope as its head, enjoyed de jure authority over the globe. ${ }^{72}$ These arguments informed the Alexandrine Bulls, which granted the Spanish Crown sovereignty over the New World on condition

69 ibid., 27.

70 Juan López de Palacios Rubios, De las islas del mar océano, trans. eds. A. Millares Carlo and Silvio Zavala (Mexico City: Fondo de Cultura Económica, I963).

${ }^{71}$ Patricia Seed, Ceremonies of Possession in Europe's Conquest of the New World, I492-I640 (New York: Cambridge University Press, I995); Annie Marie Lemistre, "Les origines du Requerimiento." Mélanges de la Casa de Velasquez, vol. 6 (I970), I 66-8I.

72 The arguments of medieval theologian Hostiensis regarding the universal dominion of the Papacy influenced Palacios Rubios and many later interpreters of the papal donations. Lemistre, "Les origines"; Bartolomé de las Casas, Del único modo de atraer a todos los pueblos a la verdadera religión, ed. Agustín Millares Carlo (Mexico City: Fondo de Cultura Económica, I975); Las Casas, Historia, vol. III, 28. See also Silvio Zavala, The Political Philosophy of the Conquest of America (Mexico City: Editorial Cultura, I953), $55-7$. 
that it actively Christianize native populations. ${ }^{73}$ The expanding horizons of the late fifteenth century suddenly turned this abstract claim into a tangible possibility. Triumphs of the faith at home seemed to connect to the dramatic news brought by Columbus, Vespucci, and da Gama. As Spaniards removed the last constraints of convivencia by ordering Jews and Muslims to convert or go into exile, they conjured up old dreams, never fully repressed, of redeeming the world under "one monarch, one empire, and one sword." ${ }^{4}$ In his memoirs, Cisneros' assistant, Juan Vallejo, inserted a song that Morisco children allegedly sang in the streets of Granada during the conversions. Mocking their broken Spanish, Vallejo's ditty parodied the combination of coercion and incentives that Spaniards employed to get Muslims to convert, since the "bonnet" - caperuza in Spanish - given in exchange for baptism could refer either to a gift or a blow to the head. Such was the attitude that was reigning in the governing circles of the Castilian Church and Monarchy in those years: the ends justified the means.

Now come King Fernando to win all of world ...

Archbishop of Toleto, you give bonnet and me Christian later

To win all of world. ${ }^{75}$

\section{SEEKING A SANCTUARY}

Gáldar, Canary Islands, I484. After two years of captivity in Spain, Tenesor Semidan was finally returning to his native island of Gran Canaria. It was undoubtedly a bittersweet homecoming. As the native

73 Anthony Pagden, Lords of all the World: Ideologies of Empire in Spain, Britain, and France, c. I500-c. I 800 (New Haven: Yale University Press, I995), 3 I-2.

${ }^{74}$ Hernando de Acuña's poem in praise of Charles V upon the seizure of Tunis in I 535. As translated in David Brading, The First America: The Spanish Monarchy, Creole Patriots, and the Liberal State (New York: Cambridge University Press, I99I), 22; original in Hernando de Acuña, Varias poesias, ed. E. Catena de Vindel (Madrid, I954), 342.

“Agora venir el Rey fernando a ganar a todo lo mundo Arçobispo de garanata cara de oveja y carne de cabra Arçobispo de toleto dar caperuça y cristiano luego Para ganar a todo lo mundo."

According to the Diccionario de la Real Academia, caperuza translates to "bonnet," but "dar en caperuza" can also mean "to hit someone in the head; to hurt someone; or to frustrate one's designs or cut one off in the middle of a dispute." Memorial, Juan Vallejo, AHN Universidades, leg. 7I6, f. 9v. 
ruler (guanarteme) of Gáldar, a fertile chiefdom on the northern side of the island, Semidan had resisted the Spanish invasion of ${ }_{4} 482$, but surrendered after hopes of expelling the foreigners faded. ${ }^{76}$ Lacking iron except for what they managed to pilfer from Spaniards, Canary Islanders had been fighting at a technological disadvantage. ${ }^{77}$ The Spanish conqueror Pedro de Vera promptly dispatched him as a royal hostage to Spain. Semidan soon found himself at the royal court of the Catholic Kings in Madrid, where he asked to be baptized. With King Fernando himself serving as his godfather, Semidan took the name don Fernando Guanarteme, a name that signaled his spiritual kinship with the king of Aragon as well as his royal status among the Guanches, the Canary Island natives. In a typical gesture to elite converts representing their incorporation into Christendom, the Catholic King dressed him in new Castilian clothes. ${ }^{78}$ Guanarteme's conversion sealed a pact between his people and the Spanish monarchy: while the Canarian ruler promised to comply with missionaries, the monarchs of Spain promised to protect native converts from enslavement, safeguard their personal property, and give them rights to "pass like Christians" and trade "without fear of captivity" in any part of Spain. ${ }^{79}$ Yet everywhere there were signs of the Spaniards' bad faith. On his way back to the Canaries, Guanarteme despaired at seeing hundreds his countrymen abused and sold at the docks of Seville. He protested to his new godparents, who promised to intervene. ${ }^{80}$

Upon his return to Gáldar, Don Fernando Guanarteme sought to turn his indigenous communities into sanctuaries from colonial violence. Spanish authorities praised him for lining up his natives to receive baptism. ${ }^{8 \mathrm{I}}$ He served as a mediator in nearby Telde, a jurisdiction where Spaniards faced stiff resistance, convincing the holdouts "with assuaging words"

${ }^{76}$ Chronicler Andrés Bernáldez equated guanarteme with rey: Memorias del reinado de los Reyes Católicos, eds. Manuel Gómez Moreno and Juan de M. Carriazo (Madrid: Real Academia de la Historia, I962), I4 I; Juan de Abreu Galindo, Historia de la conquista de las siete islas de Gran Canaria (Santa Cruz de Tenerife: Librería Isleña, I848), I42-3.

77 Bernáldez, Memorias, I38.

${ }^{78}$ Bernáldez, ibid.; Antonio Rumeu de Armas, La política indigenista de Isabel la Católica (Valladolid: Insituto Isabel la Católica de Historia Eclesiástica, I969, 51; Abreu Galindo, ibid.

79 Abreu Galindo, ibid.; Lawsuit by Canarians Juan Beltrán and Juan Cabello (I 5 I 5 ), Rumeu de Armas, Política indigenista, 222; Fray Juan de Friás against Pedro de Vera (I495), Rumeu, ibid., 308.

${ }^{80}$ Royal Provision against abuses of Canary Islanders (I485), Rumeu de Armas, Política indigenista, $23 \mathrm{I}$.

${ }^{81}$ Felipe Fernández-Armesto, Before Columbus: Exploration and Colonisation from the Mediterranean to the Atlantic I229-I492 (London: Macmillan, I987), 208-9. 
that their fight was over and that their only hope was to surrender and convert. ${ }^{82}$ The Christians would treat them well, respect their persons and possessions, and help them rebuild their community. Most of the residents surrendered, but others, including a local ruler's son, instead hurled themselves from cliffs to their deaths to avoid surrender. ${ }^{83}$ Shortly thereafter the bishop of the Canaries, Fray Juan de Frías, presided over a mass baptism of the newly subjected population. ${ }^{84}$ Guanarteme was not the sole collaborator in those years. On the island of La Palma, a native noblewoman named Francisca Gazmira also led native communities to the baptismal font. ${ }^{85}$ In the face of military defeat, slave raids, inexplicable diseases, and dwindling numbers, Canarians accepted the price of survival: the terms of the unarmed Spaniards among them - the missionaries - who at least promised to protect them under Spanish rule.

In many respects, the colonial history of America began not with Columbus' landfall at Guanahaní but with the conquests of these seven arid islands off the coast of West Africa. It was here, on this unpredictable and dangerous frontier, where Spanish politics of conversion shifted from spiritual warfare against known enemies to a mission of protecting gentiles hitherto unknown to Europeans. Canary Islanders faced Castilian invasions, technological disadvantages, slave raiding, and devastating epidemics. War, disease, and exploitation changed societies in the Canaries and the Caribbean so rapidly and profoundly that natives found themselves in a crisis that could only be described as existential. Amidst the chaos they encountered the missionaries, the only unarmed group among the Spaniards, who showed a willingness to dialogue and negotiate peace. Indigenous engagement with missionaries was inseparable from their efforts to restore order, halt slave raids, and end the downward cycle of mass mortality. For missionaries, too, the unprecedented destruction that they witnessed transformed their mission into something more than just an instrument of spiritual warfare against infidels or a lonely apostolic legation in faraway lands. ${ }^{86}$ Where convivencia ended and the

${ }^{82}$ Abreu, Historia, I48-50. $\quad{ }^{83}$ Abreu, Historia, I50. $\quad{ }^{84}$ Bernáldez, Memorias, I42.

85 "Proceso de las yslas de Canaria." AGS Consejo Real, leg. I06, f. I2; Castiliansindigenous alliance, La Palma (I495), Rumeu de Armas, Política indigenista, 3 Io; Fernández-Armesto, Before Columbus, 2 Io.

86 Pedro de Leturia, Relaciones entre la Santa Sede e Hispano-America, 3 vols. (Caracas: 1959), I72; Antonio Rubial García, La hermana pobreza. El franciscanismo: de la Edad Media a la evangelización novohispana (Mexico City: UNAM, I996), 22; FernándezArmesto, Before Columbus, 236; Rumeu de Armas, Política indigenista, 20. 
Atlantic World began, the mission gained power because both Spaniards and natives began to associate this institution with peacemaking.

European mariners first voyaged to the Canaries in the late thirteenth century. Castilians, Portuguese, and Normans searched for gold, slaves, and souls. Europeans noted the islanders' animistic religion and their lack of iron; natives noted the invaders' weapons, boats, and icons. ${ }^{87}$ The first missionaries in the archipelago were Franciscan Minorites from Mallorca, strict adherents of the Rule of Saint Francis who viewed their work at the edge of the known world as a form of hermitage. ${ }^{88}$ Few records survive of their contact with Canarian natives. A fourteenth-century chronicle stated that the friars learned native languages, indoctrinated natives, and promoted settlement in this pastoral society: "They have been reduced to the mildness of civilized men and a human way of life, and their young men have been brought by practice to the knowledge of letters." 89 But the Minorite mission was short-lived. Missionaries had to compete with slavers, and they lacked the ability to defend natives. With warfare between natives and Europeans intensifying, the Minorites left the islands in the I390s.

The failure of the Minorite mission taught an important lesson to the next missionaries who arrived in the archipelago: the mission would need to embrace worldly power if it was to found a new Church. Fifteenthcentury missionaries in the Canaries were Observant Franciscans, a reform that co-opted the Minorites' asceticism but pledged full obedience to papal and secular authority. ${ }^{90}$ In effect, the Observants both rejected the world and yet acquired power in it. ${ }^{9 \mathrm{I}}$ They managed to convert a handful of native leaders to Christianity in the I420s, but slave raids ravaged native communities and undercut their legitimacy. The Observants understood that unless they could protect converts natives would have little incentive to convert. To protest the slave raids against

87 Bernáldez, Memorias, I38, I35-9; José Rodríguez Moure, Historia de la devoción del pueblo canario a la Virgen de Candelaria (Tenerife, I9I3), I 5-40.

${ }^{88}$ Fernández-Armesto, Before Columbus, 236; Rumeu de Armas, Política indigenista, 20.

${ }^{89}$ Fernández-Armesto, ibid., 234, cites an anonymous Franciscan chronicle inserted in a fourteenth-century work by a Canon in Zurich.

90 Minorite missions incorporated themselves into the Observant movement, which received papal recognition at the Council of Costanza in I4I5. Rubial García, Hermana pobreza, 26.

${ }^{11}$ García Oro, Prehistoria y primeros capitulos de la evangelización de América (Caracas: Ediciones Trípode, I988), 60-I; Rumeu de Armas, Política indigenista, 29. 
their converts, a group of missionaries sailed to Rome with two native converts in $1434 .^{92}$

The visit by the Canarian converts prompted Pope Eugenius IV to establish a vital legal precedent for subsequent transoceanic missions. The bull Regimini Gregis exempted all Canarian converts from enslavement. To enforce the policy, the Papacy resorted to its moral economy of indulgence and excommunication: all those who manumitted Canarian slaves received a plenary indulgence, while anyone who enslaved Canarians in mission areas were to be cast out of the Church. ${ }^{93}$ Shortly thereafter several native leaders signed peace treaties with the missionaries. In I462, Pope Pius II recognized these pacts with the bull Pastor Bonis, which granted protection to all native communities that agreed to receive missionaries. In practice these policies had the unintended effect of distinguishing zones of legal enslavement, or bandos de guerra, from protected mission zones called bandos de paz. Thus in a cruel circular logic, the presence of the mission clarified the areas where European slavers could lawfully capture Canarians to sell in Andalusian ports, a threat that induced Canarians to ask for friars and baptism. Slaving and missionizing were thus antithetical but symbiotic, and after the papal bulls of the I460s and I470s, both activities intensified. ${ }^{94}$

In this context, a reinvigorated Spanish Crown under Fernando and Isabel asserted royal authority over the archipelago in the I470s. Coopting papal policies, they issued decrees that reinterpreted the bulls in their favor. In I476, after Pope Sixtus VI banned the enslavement of Canarian converts, Fernando and Isabel seconded the ban but added that Castilians could legally enslave all unconverted natives as infidels. ${ }^{95}$ At the same time, they also made clear the incentive of conversion by declaring that all native Christians were their free vassals with full rights under Castilian law. ${ }^{96}$ The royal legislation thus made conversion a fundamental condition of peace. In this way frontier violence induced natives to convert. Without qualms Fernando and Isabel defined their new policy without qualms: "the conquest proceeds by preaching as much as by force of arms." 97

92 Fernández-Armesto, Before Columbus, 236.

93 Rumeu de Armas, Política indigenista, 32. ${ }_{94}$ García Oro, Prehistoria, 92.

95 Rumeu de Armas, ibid., 40.

96 Reyes Católicos to Pedro Osorio, Alcaide de Palos (I477), Rumeu de Armas, ibid., I63.

97 Royal Provision to Andrés de Zumis, apostolic nuncio (I479), Rumeu de Armas, ibid., I90. 
In 1478 , the Catholic Kings forged an alliance with Observant missionaries in the conquest of the densely-populated islands of Gran Canaria, La Palma, and Tenerife. Over the protests of some missionaries who feared that royal sponsorship would compromise their apostolic ideals, the Catholic Kings assumed control over the missionaries' funds of indulgence raised in the streets and churches of Spain. They named the Bishop of the Canaries, the Franciscan Fray Juan de Frías, as the commander of the conquest of Gran Canaria. The extraordinary appointment confirmed the incorporation of the Observant mission enterprise, which the monarchs now funded and regulated, into their project "to submit the island to the Crown, and to expel ... all superstition and heresies of the Canarians and other pagans of those islands." ${ }^{98}$ Frías coordinated military incursions and negotiated with native leaders like Tenesor Semidan, soon to be baptized as don Fernando Guanarteme.

By the time Columbus sailed through the Canaries on his first voyage across the Atlantic, conversion had already become a legal foundation for relations between overseas indigenous populations and Spaniards. We see this in the Alexandrine Bulls, which lent themselves to be read as an injunction to protect all native converts. ${ }^{99}$ This was the opinion of Queen Isabel herself, who took offense at Columbus' trafficking in enslaved Caribbean natives in Spanish ports and at Court. Isabel also commanded that all natives in the Caribbean, especially those who received Christianity, were to be protected from enslavement and dispossession. ${ }^{100}$ Some years later, the Laws of Burgos reaffirmed that all natives in the Caribbean were free vassals of the Crown, which committed itself to supporting their instruction in Christianity. ${ }^{\mathrm{IOI}}$

Yet the promise of peace turned out to be evanescent, especially when it was more profitable for Spaniards to remain at war. When Spaniards conquered the last island in the Canaries, Tenerife (I493-I497), they flatly rejected native offers to convert. Their reason, according to royal

$9^{8}$ Accord between Catholic Kings and Bishop of Rubicón (Canary Islands), Fray Juan de Frías (I478), Rumeu de Armas, ibid., I78.

99 Pagden, Lords of all the World, 32, 52.

${ }^{100}$ Frank Moya Pons, La Española en el siglo XVI (Santo Domingo: Editorial Taller, 1978), 25 I-3; Pagden, Fall of Natural Man, $3 \mathrm{I}$.

ror Johannes Meier, "The Beginnings of the Catholic Church in the Caribbean," in Christianity in the Caribbean: Essays on Church History, ed. Armando Lampe (Kingston: University of the West Indies Press, 200I), 7-8; Pedro Fernández Rodríguez, Los dominicos en la primera evangelización de México (Salamanca: Editorial San Esteban, I994), 59-6I. 
chronicler Andrés Bernáldez, was "the tremendous cost" that the conquerors had incurred in the conquest: conversions would have narrowed the pool of slaves, and thus it was more profitable to keep the natives as infidels marked for enslavement. ${ }^{\text {IO2 }}$

These tensions between spiritual and material profit appear to have riven the dual monarchy of the Catholic Kings. Isabel issued edicts and held councils of theologians to strengthen the protection of the new converts, whereas her husband Fernando defended his rights to employ slaves. ${ }^{103}$ Conquistadors like Pedrias Dávila read the requerimiento solely as a pretext for enslaving native populations before they had time to consider the option of conversion. ${ }^{\mathrm{IO}}$ Moreover, although royal legislation outlawed enslaving converts, it still allowed Spanish colonial officials to compel them to labor as long as this did not impede their indoctrination. ${ }^{105}$ Spaniards in the Canaries and the Caribbean never resolved these conflicts between slaving and conversion before populations in both archipelagos fell victim to perilous cycles of disease and exploitation. ${ }^{\text {I06 }}$ Even Peter Martyr, the Italian humanist who spent three decades publicizing Spanish exploits in the New World for European readers, despaired of the collapse of societies in the Caribbean. ${ }^{107}$

The principal challenge for native rulers after surrender and conversion was keeping Spaniards to their word. Canarians saw their children sold into slavery, Caribbean converts suffered the burden of forced labor, and the children of Iberian converts from Islam and Judaism faced constant doubts regarding the sincerity of their Christianity. ${ }^{108}$ Time and again, natives discovered the limits of Christian sanctuary from colonial violence. Yet they struggled on, defending the sincerity of their baptisms in order to hold on to their titles, lands, and homelands. The question that a Granadan imam raised in a clandestine gathering to converted Moors some years after their mass conversion would no doubt echo in similar

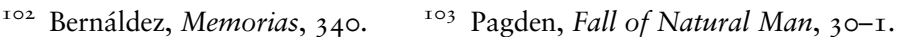

${ }^{104}$ BRAH Col. Muñoz, vol. 57, signatura 9/4837, ff. 423-32v; Meier, ibid., Io-2; Fernández Rodríguez, ibid., 47-54.

105 Fernández Rodríguez, Los dominicos, 54-5.

${ }^{106}$ Las Casas, Historia, vol. III, 270-3; Moya Pons, La Española, 25 I-3; IO-2, I4-20; Massimo Livi-Bacci, "The Depopulation of Hispanic America after the Conquest." Population and Development Review, vol. 32, no. 2 (2006), 200. Minutes of discussions at Court (I 524), BRAH, Col. Muñoz, vol. 57, signatura 9/4837, f. 377v.

${ }^{107}$ Brading, ibid., I7.

ro8 AGS Patronato Real, leg. 68, f. 64; AGS, Cámara - Cédulas, lib. 263; AHN Universidades: f. 28.
} 
gatherings on Atlantic islands, in the altepeme of central Mexico, and under the distant skies of the Pacific:

If the King of the Conquest does not keep his good faith, what are we to expect of his successors? ${ }^{\text {109 }}$

\section{CONVERGING HISTORIES}

Not long after Cortés made landfall on Mexican shores in I 5 I9, missionaries and natives raised a new mission Church that had roots in the Mesoamerican, Iberian, and early Atlantic experiences of religion and conquest: religion as a marker of sovereignty, religion as conquest, and religion as sanctuary. These attributes coincided, often uneasily, in the mission enterprise. A web of Mesoamerican communities accustomed to absorbing foreign deities engaged the Iberian mission, an heir to evangelical violence, a feeble protector of native gentiles, and a tired witness to their enslavement and destruction. The tropics of conversion - the Canaries, the Caribbean, and the lowlands of the American continent - had thus far succumbed to disease and greed. In Central Mexico missionaries would try again, joining with indigenous communities determined to bring an end to the chaos.

The news of Mexico was electric in the Caribbean. Settlers abandoned the islands in search of worldly riches and missionaries hastened towards the spiritual promise of the Mesoamerican highlands. They carried with them experiences in the alleys of Andalusia, the crags of the Canaries, and the islands of the Caribbean. When Cortés climbed the bloodstained staircase of Ahuitzotl's Great Temple, he insisted that an image of the Virgin Mary be given a special place next to Huitzilipochtli in the main shrine. The Mexica complied and incorporated the Castilians' "goddess" into their pantheon. The conquistador, however, could not hold back his disdain for Mexicas' patron god, and in a fit of rage he took up a bar and shattered the statue. When he reported the incident in his letters, he searched for the right word to describe this foreign place of worship. $\mathrm{He}$ settled on mezquita: mosque. ${ }^{\text {IO }}$

${ }^{\text {ro9 }}$ L. P. Harvey, "Yuçe Banigas, un moro en la Granada de los Reyes Católicos," AlAndalus (1953).

${ }^{10}$ Cortés, Second Letter of Relation (I 520 ), Cartas de relación (Mexico City: Porrúa, 2005), 79-80. 